\title{
Riding the waves of change
}

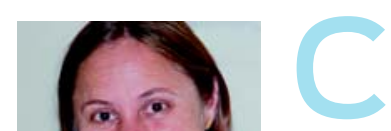

hange - in health care, its systems and community need - is one of the few certainties in medicine. A past Dean of Harvard Medical School, Sydney Burwell, put it this way in the 1950s: "My students are dismayed when I say to them, 'Half of what you are taught as medical students will in 10 years have been shown to be wrong. And the trouble is, none of your teachers know which half.'" (BMJ 1956; 2: 113-116). A broader question is: do we ride out change or ride with it?

Many contributions in this issue of the MJA highlight not only change but also the associated challenges, constructive debates needed and hard decisions to be made as medicine and health care evolve.

An obvious, pressing development is the steady increase in medical graduate numbers, which are now double what they were in 2006. This surge means that a 400-place shortfall in first postgraduate-year training positions is forecast within 4 years. These "waves" of future graduates face questions about when, where, how and even if they will complete their junior medical officer year to become fully registered practitioners. Kevat and Lander (page 334) are concerned that the states' "priority system" for selecting interns discriminates against interstate applicants, including those trying to return to their home state. Highlighting the Australian Capital Territory graduates now considered interstate applicants by the New South Wales system, they argue that this system contravenes the Australian Constitution. It is an issue that may be resolved not by the health system but in a court of law.

More medical students and graduates mean more competition for clinical experience as well as training positions. The new national registration standard will allow greater flexibility in obtaining the requisite clinical experience during internship. For example, Gosbell and colleagues (page 313) say that the new standard will allow emergency medicine rotations to be done outside of emergency departments, including in some general practice settings. Although access to placements may improve, they say the accompanying national accreditation framework must prevent any dilution of clinical experience.

The quality and extent of students' clinical experiences may affect their later careers. As de Costa and Rane (page 307) discuss, greater student numbers and the demands of other newer disciplines in medical courses mean that not all medical schools require their students to perform normal deliveries in obstetric rotations. What would the Australian community think if it was generally known that some of our doctors may be graduating without the experience of at least assisting in uncomplicated labour? And what of interns' confidence levels if they are required to manage labour in regional and rural rotations?

One might wonder whether core clinical experience is being overridden by the introduction of new subjects to medical education. But at least one of these curricular developments may be truly needed, owing in part to the increasingly international orientation of medical schools and their students. As Law and colleagues (page 324) report, around one in four medical students undertake overseas electives in developing countries, with attendant personal risks and educational benefits; accordingly, briefings before and debriefings after such terms need to be scaled up. Mitchell and colleagues (page 316) advocate formal postgraduate global health training, in line with North American courses, focusing on international health equity and fieldwork.

Change in any aspect of the medical profession and health care inevitably raises the perennial question: what is the purpose of medical education? Today, as it was 50 years ago, there is no clear, single answer. But continuing renewal and adaptation to medicine's evolving circumstances would seem necessary. The question today is how we can continue to adapt successfully to the changing tides.

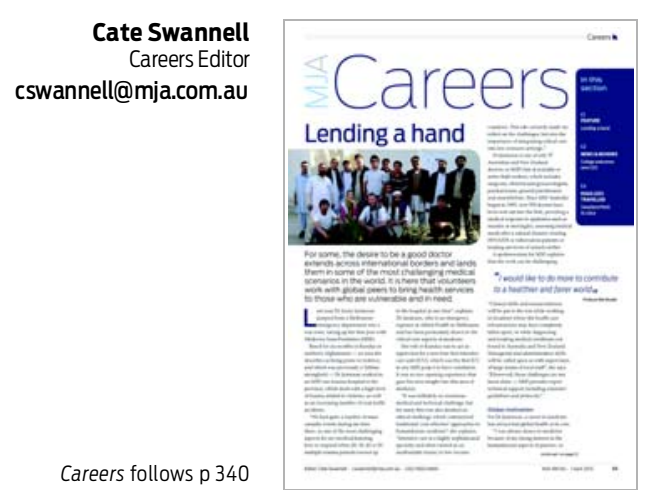

Careers follows p 340

\section{Have stethoscope, will travel}

For some, the desire to be a good doctor extends beyond country borders and lands them in some of the most challenging medical scenarios in the world. It is there that volunteers work with global peers to bring health services to those who are vulnerable and in need. Karen Burge talks with Dr Jenny Jamieson, who worked with Médecins Sans Frontières (MSF) in Afghanistan, and Professor Rob Moodie, whose overseas aid work began in refugee health care in the eastern Sudan for the Save the Children Fund and MSF (page C1). One doctor whose life, both personally and professionally, was changed forever by his overseas aid experience is Dr Maithri Goonetilleke, a Sri Lankan-born Aussie who went to Swaziland in his fifth-year elective, at the height of that nation's HIV/AIDS epidemic. He came home and formed Possible Dreams International (PDI), a non-government aid organisation which provides housing, transport and medical supplies for the Swazi. Cate Swannell caught up with Dr Goonetilleke on the PDI choir's recent tour of Melbourne (page C4). 